\title{
STUDY OF THE CHROMIUM LAYER USING GDOES, OPTICAL MICROSCOPY AND EDX MICROANALYSIS ON A SCANNING ELECTRON MICROSCOPE
}

\author{
${ }^{1}$ Petra VÁŇOVÁ, ${ }^{1}$ Jiřina VONTOROVÁ, ${ }^{1}$ Kateřina KONEČNÁ, ${ }^{1}$ Karolina SLAMOVÁ \\ ${ }^{1}$ VSB - Technical University of Ostrava, Ostrava, Czech Republic, EU, \\ ïrina.vontorova@vsb.cz
}

https://doi.org/10.37904/metal.2021.4189

\begin{abstract}
The article compares the methods of analysis of the surface chromium layer on two chromium-plated samples under the same technological conditions. However, both samples were visually different. The base material was analysed using GDOES analysis. The carbon and sulphur contents were refined by elemental analysis. The surface layers were evaluated by optical microscopy, glow discharge optical emission spectrometry (GDOES) and EDX microanalysis on a scanning electron microscope. The microhardness of the chromium layer was also measured. There was about a 10\% difference in the thickness of the chromium layer and a $5 \%$ difference in its hardness. A more significant proportion of transverse cracks occurred in the layer of one sample. It can lead to more wear and corrosion of the product.
\end{abstract}

Keywords: Chromium layer, GDOES, scanning electron microscopy, optical microscopy, EDX microanalysis

\section{INTRODUCTION}

The main task of surface engineering is to provide corrosion protection and treat the external appearance of the product $[1,2]$. One of the most frequently used anti-corrosion treatments is chrome plating. Chromium is the hardest of all elemental metals; the Brinell hardness is $1120 \mathrm{MPa}$. Chromium is chemically very resistant [3]. It is very easy to passivate under oxidizing conditions, so it behaves like a noble metal, and the chromium coatings retain their gloss. The isothermal oxidation of pure chromium depends on the average grain size [4].

Chromium plating results in increased surface hardness so that the components are protected against abrasion. Chromium plating is divided into two groups: decorative chromium plating (mostly for steel in the three-layer Cu-Ni-Cr coating; coating thickness is usually 0.25-1 $\mu \mathrm{m}$ ) and hard chromium plating (according to ČSN (Czech national Standard) EN ISO 6158 [5]), which is the subject of the presented article. During hard chromium plating, chromium coatings are deposited directly on steel components without intermediate layers. Coating thicknesses range from $25 \mu \mathrm{m}$ to $500 \mu \mathrm{m}$. The appearance, gloss, and structure of chromium coatings depend on working conditions, namely temperature and current density, less on the composition of the bath. In hard chromium plating, the deposited layers have a high hardness and are applied to the functional surfaces of wear-resistant components (shafts, cams, pressing moulds, functional profile gauge edges etc.). They are also used in the renovation of components in the repair industry.

Chromium plating is an electrochemical (or galvanic) plating. The process of galvanic chromium plating is different from other methods of electrolytic deposition of metals because the precipitated $\mathrm{Cr}$ is not supplied by dissolving the chromium anode but in the form of an anion in the electrolyte formed by chromic acid [5].

The technological process in galvanic plating consists of the following operations: chemical degreasing, rinsing, electrochemical degreasing, rinsing, pickling, rinsing, decapping, plating, rinsing, drying [6]. 


\section{EXPERIMENTAL MATERIAL}

The subject of the experimental part of the article was the comparison of two chromium-plated samples under the same technological conditions. The first sample (sample A) had a metallic grey chrome layer, the second sample (sample B) had a rust-coloured surface (see Figure 1).
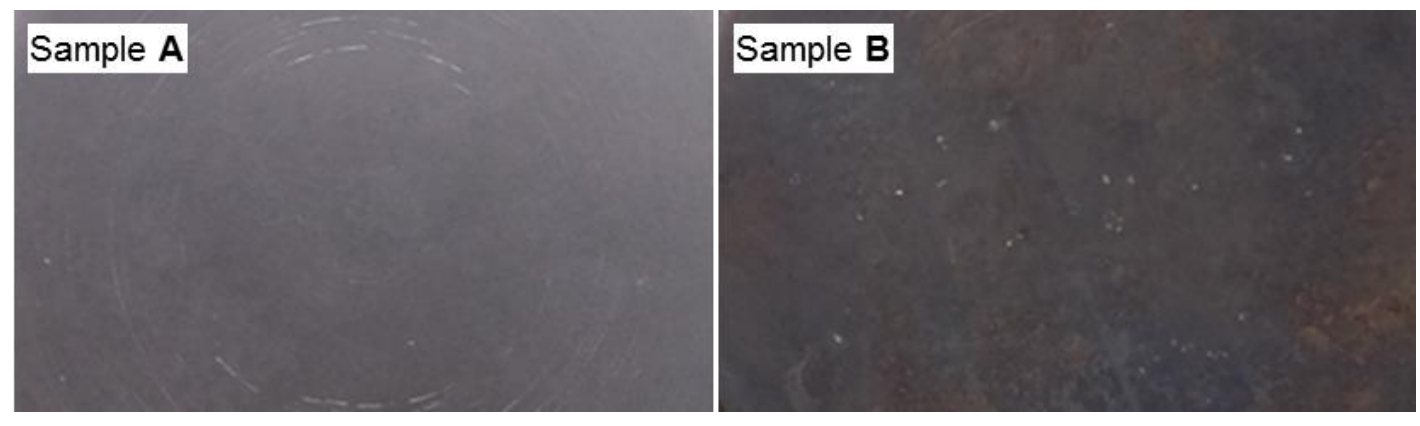

Figure 1 Samples of chrome-plated sheets

The base material of both samples was analysed by GDOES and elemental analysis (see Table 1), and it was confirmed that it was identical base material. It was unalloyed low-carbon steel.

Table 1 Chemical composition of the base material of both samples (wt.\%)

\begin{tabular}{|c|c|c|c|c|c|c|c|c|}
\hline \multirow{2}{*}{ sample } & C & Mn & $\mathrm{Si}$ & $\mathbf{P}$ & s & $\mathrm{Cr}$ & $\mathrm{Ni}$ & Mo \\
\hline & \multicolumn{8}{|c|}{ wt. \% } \\
\hline A & 0.184 & 1.21 & 0.254 & 0.009 & 0.003 & 0.111 & 0.029 & 0.008 \\
\hline B & 0.183 & 1.22 & 0.253 & 0.010 & 0.003 & 0.111 & 0.030 & 0.008 \\
\hline \multirow{2}{*}{ sample } & $\mathrm{Cu}$ & $\mathrm{Ti}$ & Co & B & $\mathrm{Pb}$ & V & W & Al \\
\hline & \multicolumn{8}{|c|}{ wt. \% } \\
\hline A & 0.026 & $<0.001$ & $<0.001$ & 0.0002 & $<0.001$ & 0.019 & $<0.001$ & 0.032 \\
\hline B & 0.026 & $<0.001$ & $<0.001$ & 0.0004 & $<0.001$ & 0.020 & $<0.001$ & 0.031 \\
\hline
\end{tabular}

\section{EXPERIMENTAL METHODS}

All these devices are operated at the Faculty of Materials Science and Technology, VŠB - Technical University of Ostrava.

\subsection{Glow discharge optical emission spectroscopy (GDOES)}

An optical emission spectrometer with a glow discharge Spectruma Analytik GMBH (model GDA 750) was used in this work. The average chemical composition of the base material of the samples was determined by BULK GDOES analysis under excitation conditions of $700 \mathrm{~V}$ and $35 \mathrm{~mA}$. The profile analysis was performed under excitation conditions of $1000 \mathrm{~V}$ and $15 \mathrm{~mA}$. GDOES Profile GDOES is used for evaluation of the quality and thickness of hot-dip galvanized coating [7], cobalt alloy films [8], organic substances [9]. It is not possible to use traditional GDOES for non-conductive surfaces, but it is necessary to use radio-frequency glow discharge optical emission spectroscopy (RF-GDOES) [10,11].

\subsection{Elemental analysis}

The carbon and sulfur contents of the base material were also determined using elemental analysis in the induction furnace of the ELTA CS 2000 elemental analyser. Elemental analysis is one of the most sensitive and accurate methods to determine the total carbon and sulfur content in organic and inorganic matrices. This 
method also determines the carbon and sulfur contents of steels, cast irons, non-ferrous alloys, slags, as well as nanomaterials and organic materials [12].

\subsection{Optical microscopy}

Samples were cut on Struers devices and were mounted into hot mounting resin with carbon filler (Struers). The samples were then grounded using $\mathrm{SiC}$ papers and polished using a diamond suspension. Documentation of the layer thickness was performed in cross section using an inverted metallographic microscope (Olympus GX51). With its chemical composition, the structure is a primary characteristic of metallic materials [13,14].

\subsection{Determination of microhardness}

Vickers microhardness (HV) was measured using a microhardness tester (LECO AMH 2000) with a load of $0.1 \mathrm{~kg}(0.981 \mathrm{~N})$ on a transverse metallographic section according to ČSN EN ISO 4516 (Metallic and other inorganic coatings - Vickers and Knoop microhardness tests).

\subsection{EDX microanalysis}

The chemical composition of the chromium layer was determined by semi-quantitative $\mathrm{X}$-ray microanalysis on a JEOL 6490LV scanning electron microscope (SEM) in the backscattered electron (BSE) mode using EDX microanalysis. EDX microanalysis is used for the semi-quantitative determination of the elemental composition of metals [15].

\section{RESULTS AND DISCUSSION}

The chromium layer thicknesses of both samples were determined on transverse metallographic sections using an optical microscope and QuickPHOTO software (see Figure 2 and Table 2). The results show that sample B has a slightly larger thickness of the $\mathrm{Cr}$ layer (by about $8 \mu \mathrm{m}$ ). The required minimum thickness of the chromium layer was $25 \mu \mathrm{m}$. Thus, this requirement has been met. Chromium layers are characterized by the presence of a fine network of microcracks. However, if the cracks are coarse, an aggressive environment can penetrate up to the base material and subsequently corrode it.

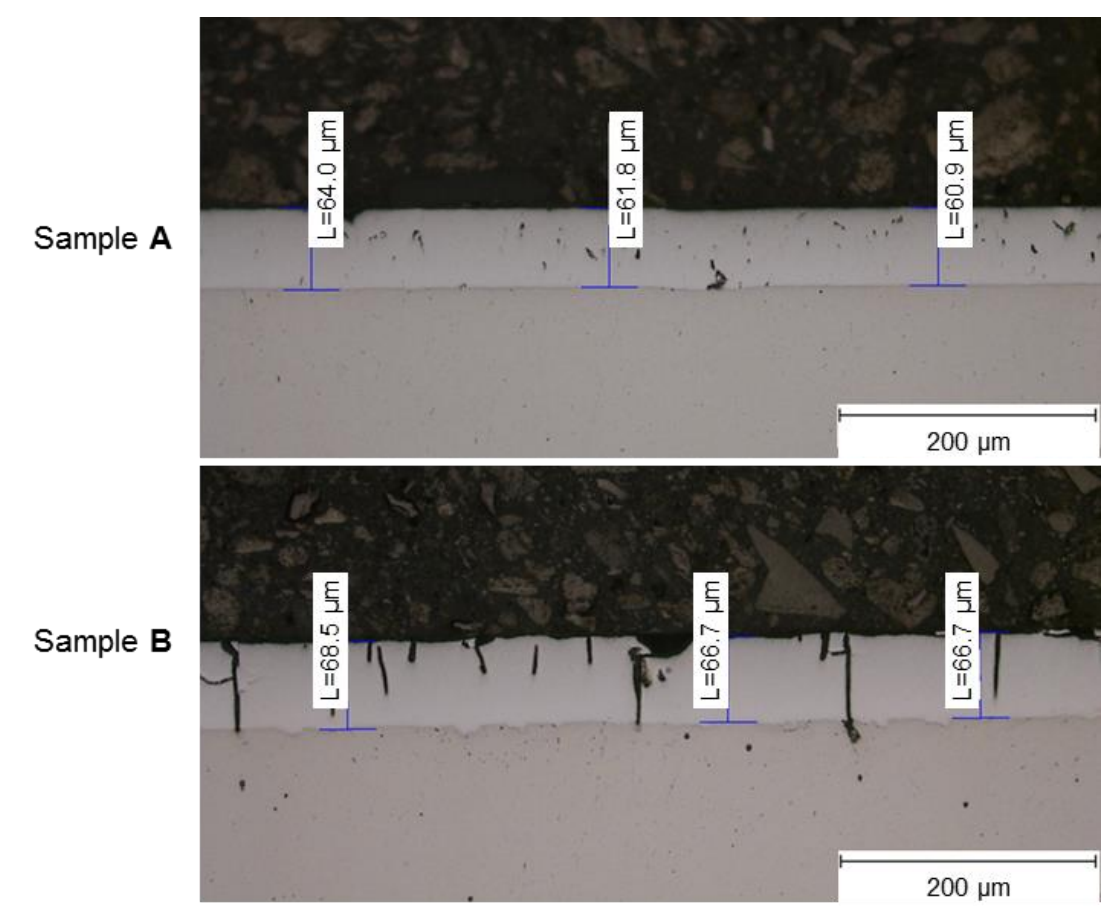

Figure 2 Optical microscopy - measurement of the Cr layer thickness 
Another important parameter of the surface layer is its hardness. Figure $\mathbf{3}$ documents the Vickers inductor impressions, and Table 2 shows the hardness values at a load of $0.1 \mathrm{~kg}$. Sample B has a slightly lower hardness than sample $\mathbf{A}$, but due to the fact that the technological requirement for this type of surface is a hardness of at least $900 \mathrm{HV}$, both samples meet the requirements.

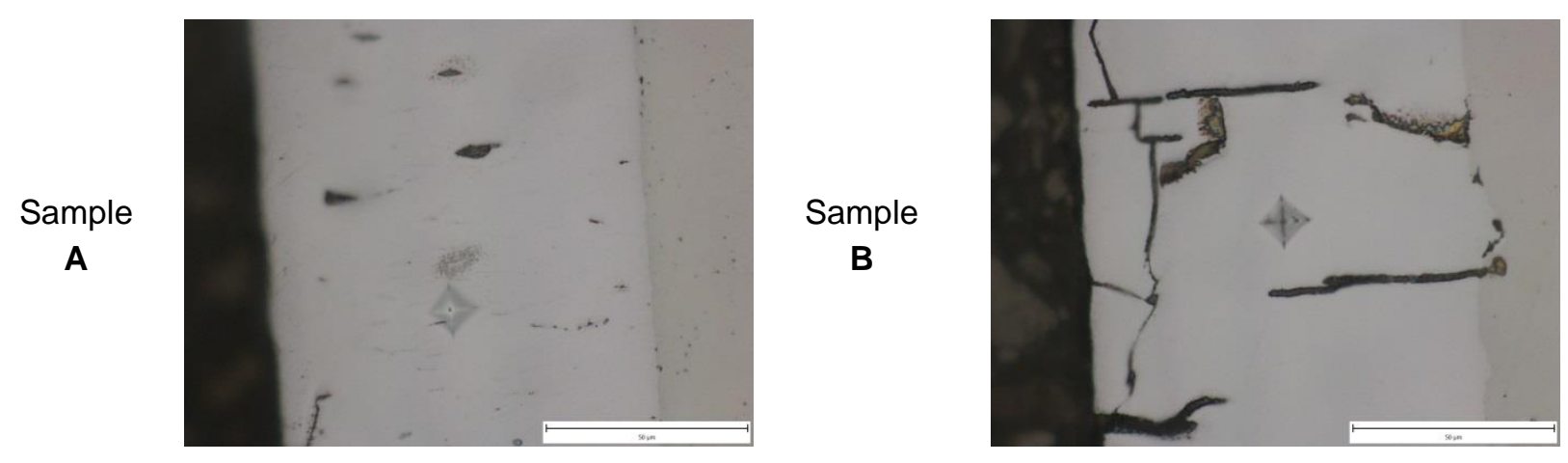

Figure 3 Optical microscopy - measurement of hardness HV0.1

Another task of this work was to verify whether it is possible to use profile GDOES analysis to determine the quality of chromium layers. Due to the high porosity of the chromium layer of sample $\mathbf{B}$, due to the highfrequency porosity of the glow discharge excitation, it was not possible to convert the analysis time to the crater depth using the GDOES spectrometer software. For the samples, it was possible to determine the chemical composition of the layers. Samples of the GDOES spectra of both samples are shown in (Figure 4). Figure 4 demonstrates that the GDOES spectra of samples $\mathbf{A}$ and $\mathbf{B}$ do not differ much, which supports the results of optical microscopy. The content of $\mathrm{C}$ and $\mathrm{Mn}$ also corresponds to the result of the BULK GDOES analysis (the value resulting from the spectrum must be divided by 10 because the scale for these elements had to be changed due to their resolution).

Sample A

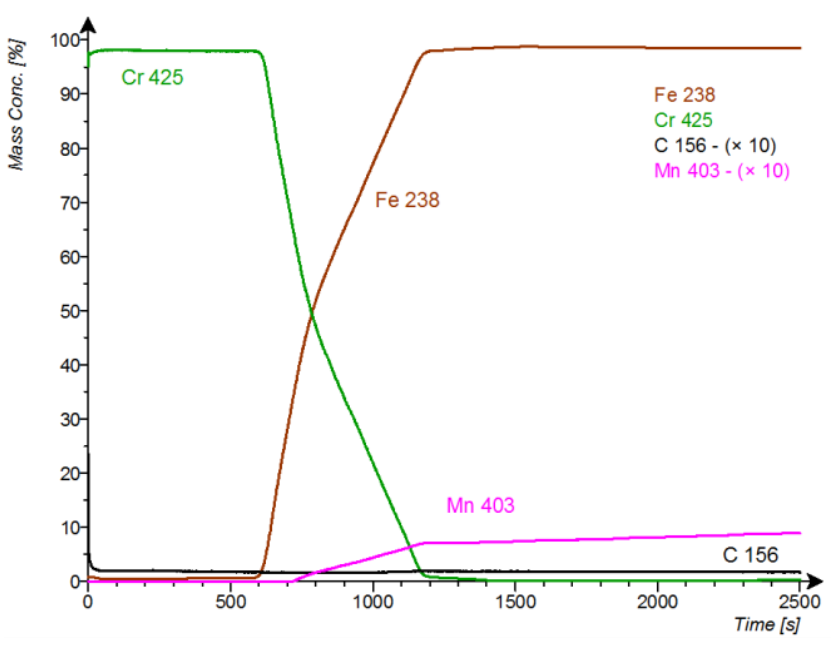

Sample B

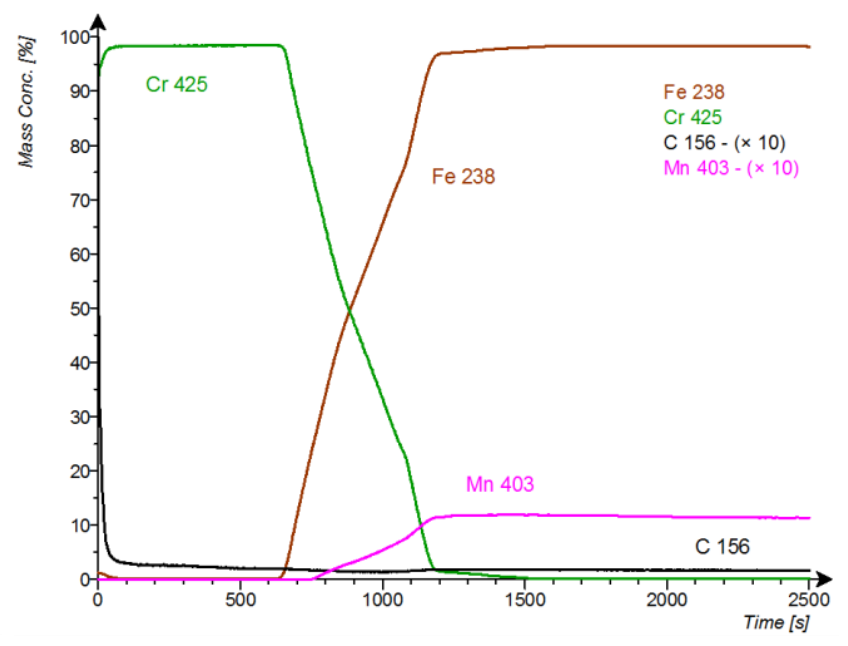

Figure 4 GDOES - profile analysis

Using SEM, it was possible to determine both the thickness of the chromium layer and its chemical composition using EDX microanalysis (Figure 5). For sample B, it can be seen that the layer was applied more than twice. Both sublayers contained $100 \mathrm{wt}$ \% chromium. Under the chromium layer, corrosion of the base material is evident in sample $\mathbf{B}$. The average chemical compositions of both the chromium layer and the base material 
below the layer are shown in Table 2. EDX microanalysis confirmed the GDOES result. An increased $\mathrm{Cr}$ content was found under the chromium layer, which is in accordance with GDOES profile analysis.

\section{Sample A}

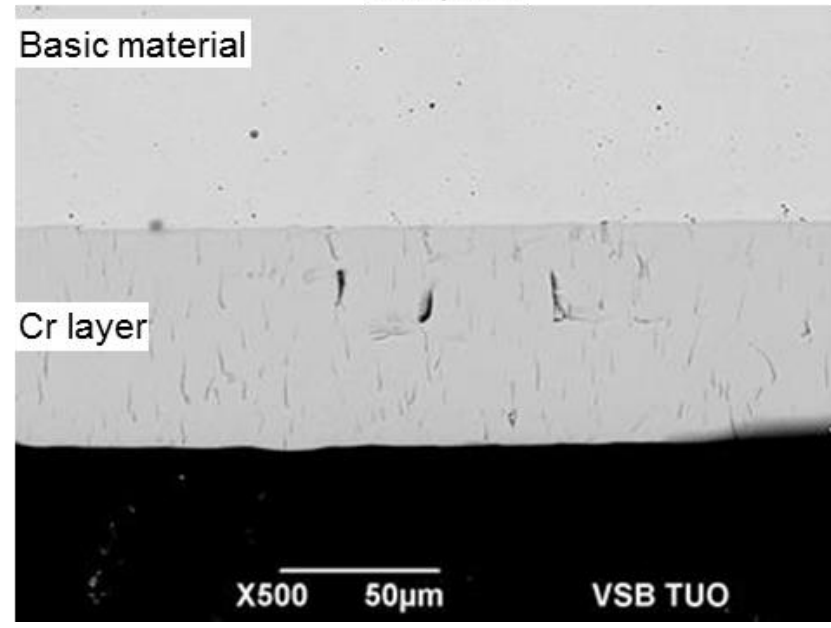

\section{Sample B}

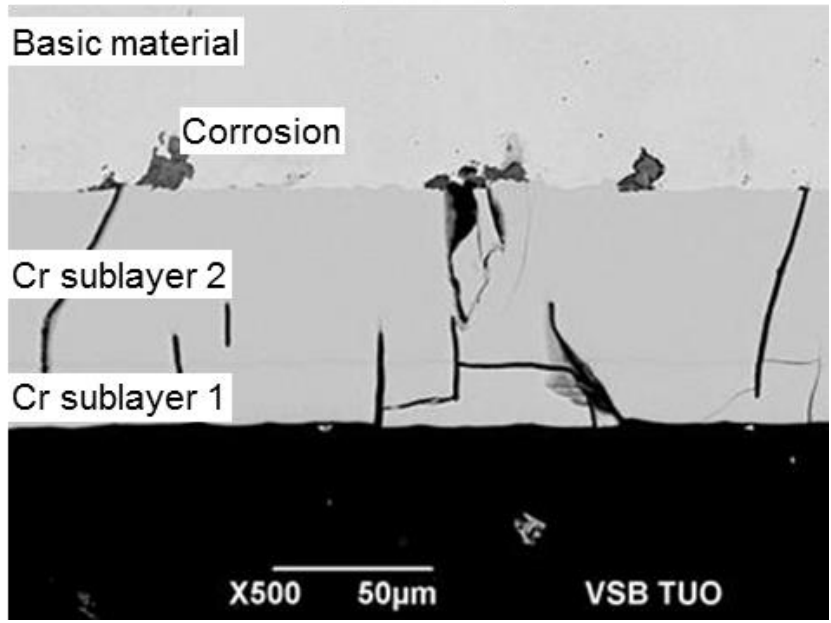

Figure 5 SEM - BSE

Table 2 Thickness, hardness, and chemical composition of the chromium layer and the base material below the layer (chemical composition determined by EDX microanalysis)

\begin{tabular}{|c|c|c|c|c|c|c|c|}
\hline \multirow{2}{*}{ Sample } & $\begin{array}{c}\text { Thickness } \\
(\boldsymbol{\mu m})\end{array}$ & $\begin{array}{c}\text { Hardness } \\
\text { HV 0,1 }\end{array}$ & $\begin{array}{c}\text { Cr } \\
\text { (wt. \%) }\end{array}$ & $\begin{array}{c}\text { Si } \\
\text { (wt. \%) }\end{array}$ & $\begin{array}{c}\text { Cr } \\
(\mathbf{w t} \%)\end{array}$ & $\begin{array}{c}\text { Mn } \\
\text { (wt. \%) }\end{array}$ & $\begin{array}{c}\text { Fe } \\
\text { (wt. \%) }\end{array}$ \\
\hline \multirow{2}{*}{ A chrome layer } & \multicolumn{3}{|c|}{ base material under the layer } \\
\hline B & $61.9 \pm 1.2$ & $1038 \pm 14$ & 100 & 0.35 & 1.1 & 1.25 & 97.3 \\
\hline
\end{tabular}

\section{CONCLUSION}

This work aimed to find out which method is most appropriate to evaluate the thickness and chemical composition of the chromium layer. The results of measurements on two samples, $\mathbf{A}$ and $\mathbf{B}$, which were prepared by the same technological procedure but whose surface differed, were compared.

The surface layer of samples A and B was evaluated by optical microscopy, glow discharge optical emission spectrometry and EDX microanalysis on a scanning electron microscope. The microhardness of the chromium layer was also compared. It was found that the second sample had a chromium layer about $10 \%$ thicker, and its hardness was about $5 \%$ lower. Coarse transverse cracks occurred in the second sample layer, which may cause higher susceptibility to corrosion in the base material. This could also affect the appearance of the surface layer. On the transverse metallographic section, two sublayers were found in sample $\mathbf{B}$, but according to EDX microanalysis, they had the same chemical composition corresponding to $100 \mathrm{wt}$. $\% \mathrm{Cr}$. The discolouration of the surface is likely to be affected only by a very thin oxide layer, which would be removed by fine grinding and polishing.

A complete idea of the thickness, structure and chemical composition of the chromium surface layer can only be obtained by SEM and EDX microanalysis. However, unlike GDOES, metallographic sample preparation is required. 


\section{ACKNOWLEDGEMENTS}

\section{This work was supported by VŠB-Technical University of Ostrava: SP2021/41, SP2021/48 and SP2021/46.}

\section{REFERENCES}

[1] PODJUKLOVÁ, J., SUCHÁNKOVÁ, K., ŠRUBAR, P., KOPANAKOVÁ, S. and HRABOVSKÁ, K. Study of influence corrosive environment on characteristics protective coatings used for long-term corrosion protection of steel substrate. In: METAL 2013: 22nd International Conference on Metallurgy and Materials. Ostrava: TANGER, 2013, pp. 953-958. WOS: 000333163100156

[2] PODJUKLOVÁ, J.: Speciální technologie povrchových úprav I. Učební texty. VŠB - TUO, Ostrava, 1997, 71 s. ISBN 80-8778-235-8

[3] ISSAGULOV, A. Z., KVON, S. S., KULIKOV, V. Y., and SAKBOSSYNOVA, A. A. Cr - Ni system alloys composition impact on durability value. Metalurgija. 2014, vol. 53, no. 4, pp. 621-623. WOS: 000335807600050

[4] MURRIS, I., JACOB, Y. P., HAANAPPEL, V. A. C., \& STROOSNIJDER, M. F. High-temperature oxidation behavior of chromium: Effect of different batches. Oxidation of Metals. [online]. 2001, vol. 55, no. 3-4, pp. 307331. Available from: https://doi.org/10.1023/a:1010364311913

[5] ČSN EN ISO 6158, Kovové a jiné anorganické povlaky - Elektrolyticky vyloučené povlaky chromu pro technické účely.

[6] MOHYLA, M. Technologie povrchových úprav kovů. 3. vyd. Ostrava: VŠB - Technická univerzita Ostrava, 2006. ISBN 80-248-1217-7.

[7] VONTOROVÁ, J., MOHYLA, P. Use of GDOES method for evaluation of the quality and thickness of hot dip galvanised coating. Transactions of the Institute of Metal Finishing. [online]. 2018, vol. 96, no. 6, pp. 313-318. Available from: https://doi.org/10.1080/00202967.2018.1520531. WOS:000447137500007.

[8] FUKUMURO, N., NISHIYAMA, J., SHIGETA, K., TAKAGAMI, H., YAE, S. and MATSUDA, H. Confirmation of hydroxide in electroless cobalt alloy films by GDOES. Transactions of the IMF. [online]. 2013, vol. 85, no. 2, pp. 111-112. Available from: https://doi.org/10.1179/174591907X179866.

[9] LIU, Y., JIAN, W., WANG, J.Y., HOFMANN, S. and SHIMIZU K. Quantitative reconstruction of the GDOES sputter depth profile of a monomolecular layer structure of thiourea on copper. Applied Surface Science, [online]. 2015, vol. 331, pp. 140-149. Available from: https://doi.org/10.1016/j.apsusc.2015.01.065.

[10] ESCOBAR GALINDO, R., FORNIÉS E. and ALBELLA J.M. Compositional depth profiling analysis of thin and ultrathin multilayer coatings by radio-frequency glow discharge optical emission spectroscopy. Surface and Coatings Technology [online]. 2006, vol. 200, no. 22-23, pp. 6185-6189. Available from: https://doi.org/10.1016/.surfcoat.2005.11.064.

[11] QIAO, L., ZHANG, X., HE, R., ZHANG, H., FU, E., \& WANG, P. Experimental measurement of deuterium concentration and depth profiling in tungsten by radio frequency glow discharge optical emission spectroscopy. Spectrochimica Acta - Part B Atomic Spectroscopy. [online]. 2020, vol.173. Available from: https://doi.org/10.1016/..sab.2020.105975.

[12] KLIKA, Z., SERENČišOVÁ, J., KOŽUŠNÍKOVÁ, A., KOLOMAZNÍK, I., STUDENTOVÁ, S., VONTOROVÁ, J. Multivariate statistical assessment of coal properties. Fuel Processing Technology. 2014, vol. 128, pp. 119-127. WOS: 000343389900014.

[13] MOHYLA, P., FOLDYNOVA, K. Effect of Post-Welding Heat Treatment on Mechanical Properties of Joints of Steel P92 Formed by Submerged Arc Welding. In: METAL SCIENCE AND HEAT TREATMENT. [online]. Springer, 2014, vol. 56, no. 3-4, pp. 206-209. Available from: https://doi.org/10.1007/s11041-014-9732-y.

[14] MOHYLA, P., ZAPLETAL, J. Investigations of Microstructure and Creep Properties of a Homogenous P92 Weld In: METAL 2011. Brno: Tanger, spol. s r.o., 2011, s. 63. ISBN 978-80-87294-24-6.

[15] DRÁPALA, J., BROŽOVÁ, S., SZURMAN, I., KONEČNÁ, K., KOSTIUKOVÁ, G., VONTOROVÁ, J., JONŠTA, P., SOBOTKOVÁ, K. Influence of selected rare earth metals on structural characteristics of $42 \mathrm{CrMo} 4$ steel. Metalurgija. 2016, vol. 4, pp. 757-760. WOS: 000376167100047. 